\title{
Fatalne zauroczenie (Wiktor Pielewin, Miłość do trzech Zuckerbrinów)
}

\author{
Fatal attraction \\ (Viktor Pelevin, Love for Three Zuckerbrins)
}

\begin{abstract}
The aim of this paper is to analyze an increasingly dangerous phenomenon in modern times - the Internet addiction - in the context of contemporary Russian literature. It seems that in this light, the work of Viktor Pelevin can serve as a perfect example of a literary voice in the discussion about the condition of the modern world. The present paper uses the findings of modern technology experts (e.g. Clifford Stoll), philosophers, and sociologists (e.g. Jean Baudrillard, Kazimierz Krzysztofek). In Viktor Pelevin's novel entitled Love for Three Zuckerbrins (Любовь к трем иукербринам, 2014) the author continues his analysis of the problem, already marked in The Helmet of Horror (Шлем ужаса: Креатифф о Тесее и Минотавре, 2005), centered on the impact of the development of the latest technologies on human beings. While in the author's earlier works this issue remained in the sphere of predictions and guesses, here it is unequivocally resolved to the detriment of the human individual. By touching upon the question of popular games for people, Pelevin shows their real role - playing with people. In this context the abovementioned attraction to simple entertainment has irreversible effects - a win in an Internet game means a failure in real life. While advocating unequivocally on the side of the opponents of the adulation for cyberspace, Pelevin points out that a complete unification with it will lead to the end of humanity.
\end{abstract}

Keywords: Victor Pelevin, Love for three Zuckerbrins, Internet, cyberculture, civilization

Aleksandra Zywert, Uniwersytet im. Adama Mickiewicza w Poznaniu, Poznań - Polska, olazywert@ o2.pl, ORCID ID: https://orcid.org/0000-0002-9922-6717

My programujemy komputery, lecz komputery programują także nas.

Clifford Stoll, Krzemowe remedium

W powieści Wiktora Pielewina Mitość do trzech Zuckerbrinów (Любовь

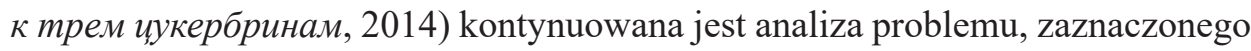
już choćby w Hetmie grozy (Шлем ужаса: Креатифф о Тесее и Минотавре, 2005), wpływu nowoczesnych technologii na człowieka. O ile we wcześniejszych utworach autora kwestia ta pozostawała jeszcze w sferze prognoz i domysłów, tu jednoznacznie zostaje rozstrzygnięta na niekorzyść człowieka. 
Od pewnego czasu naukowcy, w tym socjolodzy, podkreślają, że błyskawiczny rozwój technologii komunikacyjnych jakościowo i prawdopodobnie trwale zmienia kulturę społeczną. Wśród najistotniejszych kulturowych następstw tejże zmiany wymienia się m.in.: rekulturację techniki, „grę z ludźmi”, ikonizację komunikowania oraz nową rolę obrazu, „który nie jest już tylko prostą reprezentacją rzeczywistości [...] staje się designem wiedzy, narzędziem modelowania rzeczywistości, które rewolucjonizuje tworzenie i przekaz wiedzy" (Krzysztofek, źródło elektroniczne). Na tym tle istotnym zjawiskiem jest tzw. kultura hakerska„kultura kreatywności technologicznej opartej na wolności, współpracy, zasadzie wzajemności i nieformalności” (Krzysztofek, źródło elektroniczne) - i wykształcona na jej bazie subkultura crackerska.

Podstawowym problemem w tym kontekście jest pytanie o kształt, formy funkcjonowania i kondycję społeczeństwa informatycznego podporządkowanego pożądaniu kwalifikowanemu jako istota egzystencji nowoczesnego człowieka. Owo pożądanie w znacznym stopniu jest kreowane, a potem podsycane przez możliwości, jakie daje cyberprzestrzeń. Jedną z jej najistotniejszych w tym kontekście cech jest sposobność zastąpienia doświadczenia empirycznego symulacją. Funkcjonując w sieci jako awatar, człowiek doświadcza rozszczepienia, istnieje podwójnie: poza nią pozostaje realny i cielesny, a jednocześnie może zignorować swoją cielesność i ograniczenia z nią związane i wykreować zupełnie inną osobowość, konkurencyjną wobec rzeczywistej. Jeśli założymy za Piotrem Zawojskim, że „teleobecność [...] jest specyficzną formą kształtowania «terminalowej tożsamości» [...] często jest traktowana jako «wtórnik» rzeczywistego bycia" (Zawojski 424-425) (często lepszego, wolnego od ograniczeń i fizycznych dolegliwości czy niedoskonałości), powstaje pytanie o cenę tego sposobu alternatywnego istnienia.

Wiktor Pielewin już niejednokrotnie poruszał ten temat (co zresztą leżało u podstaw zarzutów kierowanych w jego stronę po publikacji omawianej powieści), jednak wydaje się, że nigdy jeszcze aż tak dosadnie. We wspomnianym przeze mnie Hetmie grozy autor zaledwie zastanawiał się (i to dość poważnie), na ile my, ludzkość, jesteśmy gotowi na prognozowane przekroczenie granic cielesności i wejście w świat fundujący nam (przynajmniej pozornie) nieograniczoną wolność i możliwości. Po kilkunastu latach te kwestie stały się realnością - przestrzeń ucyfrowiona trwale zmienia ludzi, pytanie tylko, czy na lepsze?

Lektura powieści (poczynając od tytułu) nie pozostawia wątpliwości, że autor patrzy na te problemy z powagą, ale też i sporą dozą ironii. Widoczne nawiązanie do bajki Carla Gozziego Miłość do trzech pomarańczy (L'amore delle tre melarance, 1761) lokuje powieść Pielewina w grupie utworów świadomie obliczonych na aż nazbyt prosty i łatwy odbiór. Dość wspomnieć, że bajka Gozziego nie jest tekstem w żadnych stopniu awangardowym. Opowiada dość błahą historię o smutnym księciu, który by zrzucić ciążącą na nim klątwę, musi zakochać się 
w trzech pomarańczach. Zbudowana na tradycyjnym motywie drogi-podróży, obfitująca w przygody, przeszkody do pokonania, walkę złych i dobrych sił, kończy się (jak każda typowa bajka magiczna) przewidywalnym szczęśliwym zakończeniem. Utwór został zaplanowany (o czym wspominał jego autor) jako satyra na twórczość Pietra Chiariego i Carla Goldoniego. Jak pisze Jolanta Dygul, chodziło głównie o teksty Goldoniego napisane dla teatru prozy (Teatr komediowy oraz La cameriera brillante) oraz jego rywalizację z Pietrem Chiarim w ramach tzw. wojny teatrów (Dygul 273-274). Ten sam satyryczny ton daje się odnaleźć w omawianej powieści i to praktycznie na wszystkich poziomach utworu, począwszy od sposobu kreacji świata przedstawionego, a skończywszy na warstwie językowej.

U Pielewina światem fantazji jest sieć. Umieszczone w tytule utworu jako pierwsze słowo miłość zakłada perspektywę osiągnięcia szczęścia za cenę bezkrytycznego uwielbienia dla Władców Cyberprzestrzeni (Zuckerbrinów), bez oglądania się na konsekwencje. Biorąc pod uwagę, że słowo Zuckerbrin jest kombinacją nazwisk dwóch potentatów w zakresie komunikacji cyfrowej (Siergieja Brina - amerykańskiego programisty rosyjskiego pochodzenia, współzałożyciela wyszukiwarki Google i Marka Zuckerberga - twórcy serwisu społecznościowego Facebook), jądrem powieści nie jest problem prognozowanego transferu świata rzeczywistego do wirtualnego (bo ten już się dokonał), a pytanie o kształt relacji pomiędzy użytkownikami sieci oraz charakter nowej wewnętrznej struktury (powstałej na drodze demontażu poprzedniej, realnej) wirtualnej społeczności. Pielewin pyta: jaki jest świat wirtualny, skoro można go bez końca „rozmnażać”? Czy rzeczywiście jest (jak głoszą reklamy) wspaniały, lepszy, dający człowiekowi upragnioną nieograniczoną moc sprawczą?

Gatunkowo powieść jest bliska antyutopii, choć - jak słusznie wskazuje Jewgienij Mielnikow - świadomie dość wtórna na wielu poziomach utworu (Mel'nikov, źródło elektroniczne). Akcja po części rozgrywa się w odległej przyszłości (XXIV wiek), a bohaterem jest Kiesza - mieszkaniec zawieszonego pięć kilometrów nad ziemią Klastra 23444-2BM - kwintesencji brzydoty i beznadziei. Pielewin pisze:

[...] кластер 23444-2Ж [...] просто жилой блок, где живут на вэлфере последние русские кряклы [...] Кластер 23444-2Ж был некрасив [...] кластер походил на заоблачное гетто. На фантастическую помойку среди облаков, какую мог бы нарисовать генетический гибрид Босха и Дали. Кластер, собственно, и являлся помойкой - свалкой отходов человеческой жизнедеятельности, самой токсичной частью которых были сами люди (Pelevin 75).

Kiesza to literat dyletant (niezbyt inteligentny, co charakterystyczne dla Pielewinowskich bohaterów), a w sieci typowy internetowy troll, który niczym matrixowski Neo à rebour jest zwykle w pełni zadowolony z życia w przestrzeni wir- 
tualnej. Wychodzi z założenia, że w sieci jest wszystko, a nawet więcej-przede wszystkim ziszczenie marzeń o nieograniczonej wolności i bezkarności. W odróżnieniu od bohatera trylogii Wachowskich Kiesza (mimo wątpliwości) nie dąży za wszelką cenę do odrzucenia cyberprzestrzeni, a odwrotnie - chce całkowicie się w niej pogrążyć, mimo zauważanych niedogodności. Można $\mathrm{w}$ tej sytuacji powiedzieć, że wykazuje on niejakie powinowactwo z ,wewnętrznym” (będącym członkiem prezentowanej jako idealna społeczności) bohaterem antyutopijnym, aczkolwiek w dość wąskim zakresie. Raczej nieco przypomina on (na co zwraca uwagę także Arsienij Steiner) karykaturalną wersję Winstona Smitha z powieści George'a Orwella Rok 1984 (Nineteen Eighty-Four, 1949) (Štejner, źródło elektroniczne) - częstokroć jest zwyczajnie śmieszny w swoim prymitywizmie, a jego walka jest wątła, mdła i pozbawiona autentyczności. Równie groteskowo zaprezentowany jest, towarzyszący konfrontacji idei, wątek miłosny. Uwielbienie dla wirtualnych bytów i cyberseksu nie ma w sobie prawdziwego dramatyzmu i żaru miłości, który cechuje klasyczne postaci antyutopijne.

Kiesza zdaje sobie, co prawda, sprawę, że ugrzązł w swojej metalowej „puszce” na zawsze i tym samym pojęcie wolności zawsze już będzie dla niego czystą abstrakcją, ale jednocześnie dostrzega w tym (paradoksalnie!) owej wolności ziszczenie. Z jednej strony system, którego jest częścią, zmienił mu nawet imię („,единственное наследство от неведомой мамочки. Она назвала его «Сhe» в честь какого-то борца за вашу и нашу, прославившегосяв двадцатом веке" - Pelevin 76) tak, by wpisywało się w strukturę lokalizacji urodzenia - „Но при локализации сертификата о рождении система превратила его в «Ке». Зато к этому «Ке» в русском языке нашлось ласковое уменьшительное - «Кеша», от иезуитского имени «Иннокентий»" (Pelevin 76) - i niwelowało jakiekolwiek odstępstwo od reguły, gwarantowało idealną, niczym niezakłóconą identyczność. Z drugiej strony Kiesza podkreśla, że „podniebne getto" ma swoje zalety (jest praktycznie bezkosztowe, wygodne i dające przeświadczenie pełnej swobody) i dlatego jest przezeń dobrowolnie zamieszkiwane. Swoje przywiązanie doń bohater wyraża choćby przez nazywanie miejsca „zamieszkania” „ojczystym klasterem” - „Кеша любовался панорамой родного кластера" (Pelevin 76).

Wydaje się, że kluczem do zrozumienia decyzji bohatera o pogrążeniu się w sieci jest specyfika realnej rzeczywistości. W klasycznej antyutopii u podstaw konstrukcji leży kontrast pomiędzy dwoma skrajnie różnymi światami, „między przestrzenią społeczeństwa zorganizowanego a przestrzenią, która pozostaje do niej w opozycji” (Wojtczak 65-66). U Pielewina ten porządek jest zaburzony, albowiem realność nie jest alternatywą dla wirtualności. Znamienny jest tu fragment, w którym bohater podczas powrotu z pracy do domu obserwuje piękny zachód słońca. W pierwszej chwili żałuje, że nie jest poza miastem, ale zaraz potem 
zdaje sobie sprawę, że tej chwili (niezależnie od miejsca jego pobytu) i tak nie da się zatrzymać.

[...] назначение красоты - терзать и мучить, поскольку по своей природе она просто обещание невозможного, и никакой другой сути у нее нет [...] но зачем материальному миру мучить и обманывать нас надеждой на то, чего в нем не бывает? Да чтобы мы продолжали здесь оставаться - и на что-то такое надеяться [...] (Pelevin 32).

Dojmujące nieustanne poczucie straty jest pogłębione przez przygnębienie wynikające z beznadziei wyzierającej z każdego zakątka najbliższego otoczenia (tu: miasta). Świat materialny przeraża swoim bezsensownym, prymitywnym okrucieństwem, bezmyślnością i straceńczym, nieuświadomionym dążeniem do samozagłady. Rosyjska miejska codzienność to przede wszystkim bardziej lub mniej wyrafinowane morderstwa. Nie ma w niej nic, co pozwalałoby przezwyciężyć absurd istnienia. Pielewin pisze:

Вокруг все было довольно ординарно: в башне через дорогу отставной судья расчленял в ванной пожилую родственницу в видах на ее деревенский дом, дети во дворе, мимо которого я шел, убивали уже смирившегося с судьбой рыжего кота, да еще в пятиэтажке неподалеку три рязанских бандита проверяли оружие перед намеченным на ночь налетом [...] Обычный городской ноктюрн (Pelevin 32).

W tej sytuacji cyberprzestrzeń wydaje się jedyną sensowną alternatywą, skuteczną ucieczką od przytłaczającej realności, tym bardziej, że mieści ona w sobie niezliczoną ilość światów realizujących wszelkie możliwe warianty rozwoju cywilizacji. Można w nich nie tylko zatrzymać „świąteczną północ nieco dłużej”, ale i realizować wszelkie swoje życiowe marzenia i fantazje. Takie, absolutnie oderwane od rzeczywistości, postrzeganie świata nie jest pozbawione podstaw, jeśli wziąć pod uwagę specyfikę współczesnej kultury. Jak wskazuje Krzysztofek, w odróżnieniu od poprzedniego, przedindustrialnego jej stadium, w tej chwili „,[p]rodukcja gotowej wyobraźni jest traktowana jako własność intelektualna. [...] Dzięki cyfrowej konwergencji telekomunikacji, mediów i komputera możliwe staje się łączenie wszystkiego ze wszystkim w przestrzeni cyfrowej. Internet daje poczucie władzy jednostce, likwiduje pojęcie tłumu, masy ludu, zmienia pojmowanie narodu" (Krzysztofek, źródło elektroniczne). Nacisk na mediatyzację wpływa także na sposób organizacji społeczeństwa. Następuje marginalizacja tłumu jako podstawy wszelkich ruchów społecznych, a jego rolę przejmuje kampania medialna - według Richarda Rorty'ego „wielkie ruchy społeczne zostaną zastąpione przez kampanie medialne, internetowe. Nawet jeśli tak się nie stanie, to z pewnością tylko dzięki Internetowi można będzie organizować akcje o zasięgu 
globalnym" - cyt. za Krzysztofek, źródło elektroniczne). Tego rodzaju kampania medialna leży u podstaw wirtualnej ojczyzny Kieszy.

Podstawowy problem polega na tym, że pomiędzy ironicznie i sarkastycznie skomentowaną (zwłaszcza, jeśli chodzi o podstawy rosyjskiej mentalności) rzeczywistością a cyberprzestrzenią nie ma zasadniczej różnicy. A raczej jest, ale na niekorzyść człowieka. Uciążliwa samotność i poczucie niespełnienia, które towarzyszy bohaterowi w kontakcie z rzeczywistością realną, nie znika podczas przebywania $\mathrm{w}$ wirtualnych światach, albowiem wymuszony $\mathrm{w}$ tym wymiarze kolektywizm ma charakter symulacyjny. Z jednej strony rzeczywiście, jak pisze Elżbieta Winiecka, ,[k]onsekwencją oddziaływania Internetu na społeczeństwo i kulturę staje się kolektywizm - nowa forma uspołecznienia, którą można wyobrazić sobie jako ahierarchiczną sieć konstruowaną z indywidualnej perspektywy. Nowy indywidualizm jest więc relacyjny - uwikłany w interakcję, uzależniony od relacji z innymi" (Winiecka 31), z drugiej jednak rzeczywista więź między uczestnikami interakcji nie istnieje. Tradycyjna komunikacja twarzą w twarz zanika na rzecz komunikacji face-to (via monitor)-face lub wręcz face-to-monitor, czyli ostatecznie zostaje wyparta przez klasyczną symulację, w której nie jest możliwe rozróżnienie modelu od rzeczywistości. Utrata oryginału, jak słusznie podkreśla Jean Baudrillard, owocuje zniesieniem właściwie wszystkich punktów orientacyjnych tradycyjnego społeczeństwa, począwszy od podmiotu i punktu centralnego, za to umożliwia ekspansję informacji [,pozostaje jedynie «informacja», tajemniczy i zjadliwy wirus, reakcja łańcuchowa, powolne zapadanie się i symulakry przestrzeni, gdzie igra efekt rzeczywistości" (Baudrillard 2005: 42)]. Po drugie, w zakresie rzeczywistej jakości życia świat wirtualny nie proponuje żadnych nowych rozwiązań, a tylko kopiuje zastane. Pozornie demokratyczny, okazuje się tak samo zdominowany przez władzę pieniądza, jak realny. Przykładowo, jedzenie jest takie samo dla wszystkich, ale już jego smak zależy od zasobności wirtualnego portfela konkretnego użytkownika - „Еда одинакова для всех - полужидкая пища: клетчатка, белок, протеины, углеводы, витамины и минералы. А вот вкус зависит от готовности тратить шэринг поинтс. Черепаховый суп может себе позволить не каждый” (Pelevin 95).

W rezultacie Internet, jak pisze Pielewin, staje się dla człowieka śmiertelnym zagrożeniem, rakową naroślą, która niepostrzeżenie wysysa z każdego użytkownika online wszelkie soki życiowe. Sprawia, że staje się on (analogicznie jak w Matrixie) biologicznym żywicielem, hodowanym i karmionym najpodlejszym, najbardziej ogłupiającym pokarmem - grami sieciowymi i porno. Nieprzypadkowo władcami świata (a ściślej: świata umysłów) są Angry Birds - bohaterowie popularnej gry logicznej polegającej na burzeniu budynków i mordowaniu zamieszkujących je świń. U Pielewina te pełne absurdalnej agresji ptaki są rzeczywistymi królami życia, ludzie zaś - przedmiotami, bezwolnymi „,̇ywicielami”, „naboja- 
mi” skazanymi na zagładę (ptaki strzelają nimi z procy). Schwytany w wirtualną sieć człowiek nie musi nic robić. Wystarczy podporządkować się systemowi, który wygeneruje wszystko, począwszy od myśli użytkownika. Pogląd ten pokrywa się z wnioskami Clifforda Stolla, który już w połowie lat 90. XX wieku zauważał, że komputer uruchamia swego rodzaju selekcję naturalną - sprzyja tym, którzy „potrafią rygorystycznie trzymać się sztywnych reguł” (Stoll 58) i odrzuca nieprzystosowanych. W ten sposób ,zmodyfikowany” biologiczny organizm jest trwale odizolowany od rzeczywistości - brudnej, zaśmieconej, wrogiej, okrutnej, lecz sztuczne wyparcie realności w praktyce oznacza krach cywilizacji.

Jednym ze zwiastunów tego zjawiska jest postępująca degeneracja społeczności opartej na strukturze symulakrów. Idealnym przykładem jest, prześmiewczo w gruncie rzeczy skomentowana, historia Batu Karajewa. Ten idol internautów, człowiek legenda („Бату Караев, самый страшный террорист современности, более известный человечеству как «Dreambomber» [...] потому что он совершает свои теракты в коллективных снах" - Pelevin 103) jest w rzeczywistości zupełnie kimś innym i nie ma nic wspólnego ze swoim oficjalnym internetowym wizerunkiem - to podłączony na stałe do aparatury podtrzymującej życie trup.

Это было похоже на кадр из фильма ужасов [...] То, что он увидел перед собой, больше всего походило на такую банку консервов, уже открытую - и сардинница, надо сказать, была ужасного содержания [...] В самом ее центре плавал мертвец. Он был в грязном халате [...] Под халатом виднелись стандартные же пластиковые памперсы со множеством отходящих от них трубок и шлангов - как на Кеше. Но на лице мертвеца не было маски „LifeBEat”. Его рот с черно-желтыми кривыми зубами был открыт. К подбородку прилип комок темной слюны. Вместо серой полоски фейстопа на его лбу громоздилась какая-то черная электронная опухоль, утыканная вычислительными микромодулями и змеящаяся соединительными лентами [...] Маска жизнеобеспечения висела в пустоте рядом с лицом мертвеца, и на самой толстой из ее трубок запеклись неаппетитные следы пищи (Pelevin 135).

Pielewinowski (nadzwyczaj rozczarowujący w swej istocie) opis ciała Karajewa w dużym stopniu ilustruje pogląd Baudrillarda, że ,technologia stanowi przedłużenie ludzkiego ciała" (Baudrillard 2005: 137), w efekcie czego ciało odgrywa wyłącznie rolę medium. Jednocześnie poprzez sugestywny, naturalistyczny sposób jego prezentacji fragment ten może być - podobnie jak analizowana przez badacza Kraksa (Crash, 1973) Jamesa Grahama Ballarda - odebrany jako swego rodzaju apogeum przemocy, jakiej doświadcza ciało w świecie symulacji.

Tak oto, co z wyraźną ironią konstatuje autor, próżna i niecierpliwa (a przez to coraz bardziej powierzchowna w swoich dążeniach) ludzkość, ulegając pokusie pozornie łatwego spełnienia, sama wpędza się w pułapkę, z której nie ma wyjścia. Ludzie sami stworzyli sobie piekło, w którym (jak słusznie wskazuje Leonid Dubakow) pozostają tylko dwa warianty funkcjonowania: pseudocierpienie 
albo pseudoszczęście (Dubakov, źródło elektroniczne). Symulakryczna rzeczywistość Internetu niezauważalnie, acz nad wyraz skutecznie wciąga człowieka coraz głębiej i uzależnia go od siebie właśnie poprzez iluzję szybkiego zaspokojenia pragnień. „Czarny polip”, o którym pisze Pielewin, nie jest, wbrew pozorom, wyłącznie płodem jego fantazji, a (paradoksalnie) coraz realniejszą perspektywą dla ludzkości. Konsumpcja, jeden z głównych symboli współczesnego społeczeństwa, wspięła się na wyższy poziom, bo internet oferuje „autentyczne symulacje” (w tym dotyczące społeczności). Dochodzi wówczas do nowego rodzaju umagicznienia przestrzeni - poprzez implozję pojmowaną jako „rozpad lub zanik granic, wskutek którego twory wcześniej uważane za różne zlewają się ze sobą" (Ritzer 225). Użytkownik sieci może ignorować zarówno bariery przestrzenne, jak i czasowe, ale to generuje rozpad kolejnych (w tym dotyczących różnych aspektów życia społecznego). Pojawia się efekt reakcji łańcuchowej, której rezultatem jest iluzja nieograniczoności w każdym wymiarze ludzkiego funkcjonowania. Mamy zatem do czynienia z dokładnie takim samym zjawiskiem, jakie opisuje George Ritzer w odniesieniu do tradycyjnej konsumpcji, tyle że już na wyższym, nienamacalnym poziomie: „Ów świat po implozji jest rodzajem spektaklu, który przyciąga klientów i skłania ich do konsumowania" (Ritzer 226). Ewidentnie dehumanizujący wpływ tego procesu przejawia się m.in. w obojętności (a czasami wręcz w okrucieństwie) w stosunku do innych ludzi, albowiem na pierwszy plan wysuwa się priorytet prostego rozumienia pojęcia „szczęścia” sprowadzonego do pozornie wykluczających się, acz trwale ze sobą zespolonych w różnych konfiguracjach elementów, mianowicie: „przyjemność, brak przykrości, satysfakcja” (Martin 180). W myśl tej zasady poczucie szczęścia powinno ostatecznie gwarantować przeświadczenie, że nasze życie jako całość jest uporządkowane i w potocznym rozumieniu udane, ale tak nie jest. Najczęściej szczęście postrzegamy jako coś nieosiągalnego i zadowalamy się szybką i łatwą do zdobycia przyjemnością. W efekcie tego jednowymiarowego procesu (pozbawionego poczucia braku przykrości) nie ma mowy o autentycznej satysfakcji, a tylko o pseudoszczęściu. Przykładowo, bohater Pielewina doskonale zdaje sobie sprawę z własnego położenia - utknął na wieczność w klastrze zawieszonym na wysokości pięciu kilometrów nad ziemią (przykrość) - pozostawia zatem ten aspekt na boku i skupia się na pozytywnych (w jego mniemaniu) stronach swojego ,życia” - prostych (wręcz prostackich) doraźnych przyjemnościach. Jedną z lepszych ilustracji tego zachowania jest scena erotycznego spotkania z Marylin/siostrzyczką (także bytami wirtualnymi), w której proste przyjemności stanowią cel sam w sobie:

Пауза.

Фейстоп.

Напудренная Мэрилин с горящим над головой рубиновым сердцем (кто бы сомневался).

Спальня. Ничего не объяснять, не уговаривать. 
Хватаем за руку и тащим $[\ldots]$

Мэрилин не спорила. Рывок назад в кинозал - в обход фейстопа. Маневр, достойный сексуально возбужденного Наполеона (Pelevin 102-103).

Analogiczna zasada dotyczy wspomnianego przez Dubakowa pseudocierpienia. Jakkolwiek unikanie cierpienia jest strategią rozsądną i racjonalnie uzasadnioną (albowiem sterujące życiem ludzkim w kryzysowych sytuacjach emocje automatycznie kierują człowieka - jeszcze przed włączeniem się świadomości - we „właściwą" stronę), to jednak ostatecznie wszelkie negatywne emocje, w tym ból rozumiany jako „przykre doświadczenie zmysłowe i emocjonalne, związane z istniejącą lub możliwą szkodą" (Martin 188), są nawet bardziej pożądane niż pozytywne, ponieważ ostatecznie spełniają funkcję ochronną przed krzywdą. W internecie emocje te są nienaturalnie złagodzone (choćby przez możliwość błyskawicznego wycofania się poprzez przejście do innego, bezpieczniejszego świata), a więc ostatecznie człowiek staje się coraz bardziej ubogi emocjonalnie, czyli w konsekwencji bezbronny wobec świata. Przykładem tego rodzaju zjawiska jest choćby epilog, w którym autor wprost pisze o istnieniu różnych światów o charakterze operacyjnym („Чего только не увидишь, путешествуя между мирами" - Pelevin 196), stworzonych na zasadzie precesji symulakrów, światów podważających „różnicę pomiędzy tym, co «prawdziwe», i tym, co «fałszywe»; tym, co «rzeczywiste», i tym, co «wyobrażone»" (Baudrillard 2005: 8).

Specyfika społeczeństwa numerycznego, które „myśli liczbami, formami, kolorami, dźwiękami, ale w coraz mniejszym stopniu słowami” (Flusser 48) znajduje swoje odzwierciedlenie również w warstwie językowej powieści. Narracja jest aż nazbyt prosta i naszpikowana anglicyzmami właściwymi dla żargonu internetowego. Są to przede wszystkim teksty komend („READ ME” - Pelevin 135) czy możliwych do wyboru odpowiedzi podczas rozmowy w sieci („Опций было две: 1) ЗДРАВСТВУЙ, БАТУ 2) ЗДРАВСТВУЙ, БУ” - Pelevin 139; „Опций опять было две: 1) НЕТ 2) НЕ ОЧЕНЬ" - Pelevin 139). Tak samo proste, nierzadko wręcz prymitywne są riposty bohaterów, jak również fragmenty dotyczące epizodów z ich wirtualnego życia (np. rozdział Гpex).

Na tym tle mocnym, bo gwałtownie przywracającym właściwe proporcje, akcentem jest epilog. Pielewin bez ostrzeżenia „odcina zasilanie” i funduje czytelnikowi błyskawiczny powrót do rzeczywistości. Ta ostatnia, niestety (co z autentyczną, jak się wydaje, troską zauważa autor), nie jest obiecująca:

Я езжу в метро и гляжу, как люди, хорошие добрые люди, сидят ровными рядами на скамейках - и, уткнувшись в экраны своих смартфонов, кормят подрастающих цукербринов. Угощают собой тамагочи, которые не собираются умирать, а будут только расти... (Pelevin 196) 
Fragment ten dobitnie pokazuje, w którą stronę zmierza ludzkość i jak się zmienia. Socjologowie (jak choćby Krzysztofek) od dawna wskazują, że nadmierne korzystanie z internetu trwale zmienia ludzkie postrzeganie świata i formy funkcjonowania w nim. Chodzi tu głównie o zanik niektórych kompetencji komunikacyjnych i rozpoznawania (przede wszystkim niewerbalnych) kodów typu mimika czy ton głosu. Świadczy to o zmianach funkcjonowania mózgu. Równolegle rozpowszechniona coraz większa kondensacja komunikacji (SMS, tweet, post) sprzyja zanikowi umiejętności długotrwałego skupienia - pogarsza się zdolność rozumienia dłuższych tekstów, a więc zmienia się sposób myślenia. Według Krzysztofka, na aktualnym etapie badań jeszcze trudno jednoznacznie stwierdzić, czy owe zmiany są wyłącznie negatywne, jednakże nie można wykluczyć czarnego scenariusza (Czauderna, źródło elektroniczne). Pielewin tak ostrożny nie jest i staje jednoznacznie po stronie przeciwników uwielbienia dla cyberprzestrzeni, wskazując, że tzw. terminalowa tożsamość odcina człowieka od świata i całkowicie go ubezwłasnowolnia. W tym układzie „bilet do raju” oznacza w praktyce, że „,dobrowolnie przekształcamy się w zdepersonalizowane strumienie danych, w wehikuły, które przenoszą niezliczoną ilość informacji, ale są traktowane wyłącznie jako narzędzia - do transmisji, odbioru" (Zawojski 425). Z tym wnioskiem konweniuje także pogląd Baudrillarda, podkreślającego, że w jakościowo nowym sposobie funkcjonowania człowieka trwale zmienia się też sposób postrzegania własnego ciała - przesuwa się ono na daleki plan w hierarchii ludzkich priorytetów. Baudrillard pisze: „nie chodzi o to, żeby mieć ciało, ale by być podłączonym (connected) do swojego ciała [...] do swojego mózgu" (Baudrillard 1994: 249-250). Uwikłany w borgesowski labirynt świata internauta ugrzęźnie w nim i jedyne, co będzie mógł zrobić, to przemierzać niekończące się korytarze pozornych, odgórnie zaprogramowanych wyborów. Myśl ta, choć zaledwie w formie sugestii, pojawiła się wcześniej np. w finale wspomnianego Hetmu grozy. Z jednej strony bohaterowie są zachwyceni nieograniczonymi możliwościami (,зато теперь будем Минозавром [...] будем драконом. Взлетим под облака, нырнем на дно морское" - Pelevin, źródło elektroniczne), z drugiej jednak strony na ich euforii kładzie się cieniem perspektywa wiecznego dyskomfortu - „Нас все время теперь будет тошнить [...] Шлем не снимается" (Pelevin, źródło elektroniczne). Wówczas jednak jeszcze nic nie było przesądzone. W tej chwili (czego świadectwem jest forma epilogu Miłości...) już tego dylematu nie ma. Wychodząc od popularnych gier dla ludzi, Pielewin pokazuje, że ich prawdziwy, wymyślony przez Władców Umysłów cel to (analogicznie jak w Martixie) gra ludźmi. W tym kontekście owo wspomniane w tytule pracy zauroczenie nieskomplikowaną zabawą jest rzeczywiście fatalne, bo jego skutki są nieodwracalne, dochodzi bowiem do paradoksu - zwycięstwo w internetowej grze oznacza przegraną w realnym życiu. 


\section{Bibliografia}

Baudrillard, Jean. Symulacja i symulakry. Przeł. Sławomir Królak. Warszawa, Sic!, 2005.

Baudrillard, Jean. „Świat wideo i podmiot fraktalny”. Po kinie?... Audiowizualność w epoce przekaźników elektronicznych. Wyb., przeł. i opr. Andrzej Gwóźdź. Kraków, Universitas, 1994, s. $247-258$.

Czauderna, Piotr. Technologia nas ogtupia? Nasz umyst się zmienia. Web. 01.08.2019. https://natemat.p1/3531,technologia-nas-oglupia-nasz-umysl-sie-zmienia.

Dubakov, Leonid. Viktor Pelevin. Lûbov'k trëm cukerbrinam. Web. 01.08.2019. https://www.proza. $\mathrm{ru} / 2015 / 05 / 19 / 664$.

Dygul, Jolanta. Metateatralność w dramaturgii Carla Goldoniego. Warszawa, Wydawnictwa Uniwersytetu Warszawskiego, 2012.

Flusser, Vilém. „Społeczeństwo alfanumeryczne”. Przeł. Andrzej Kopacki. Lettre Internationale 1993/94, s. 45-50.

Krzysztofek, Kazimierz. Internet: Edukacja - Kultura - Ekskluzja społeczna. Web. 03.08.2019. https://www.nck.pl/upload/archiwum_kw_files/artykuly/2._kazimierz_krzysztofek_-_internet_-_edukacja_-_kultura__ekskluzja_spoleczna.pdf.

Martin, Paul. Seks, narkotyki i czekolada. Przeł. Anna Dzierzgowska. Warszawa, Muza SA, 2010.

Mel'nikov, Evgenij. Kniga: „Lûbov' k trem cukerbrinam”. Viktor Pelevin. Novyj roman glavnogo mistifikatora sovremennoj literatury. Web 12.07.2019. http://newslab.ru/article/610147.

Pelevin, Viktor. Lûbov' k trem cukerbrinam. Moskva, Èksmo, 2014.

Pelevin, Viktor. Šlem užasa: Kreatiffo Tesee i Minotavre. Web 12.07.2019. http://loveread.ec/view_ global.php?id=2944.

Ritzer, George. Magiczny świat konsumpcji. Przeł. Ludwik Stawowy. Warszawa, Muza SA, 2012.

Štejner, Arsenij. Mistik uglevodorodnoj epohi. Novyj roman Viktora Pelevina - o našestvii kremnevoj civilizacii, cene podpol'noj mudrosti i zlyh pticah s rogatkoj. Web. 03.08.2019. https:// lenta.ru/articles/2014/09/09/pelevintxt/.

Stoll, Clifford. Krzemowe remedium. Garść rozważań na temat infostrady. Przeł. Tomasz Hornowski. Poznań, Dom Wydawniczy Rebis, 2000.

Winiecka, Elżbieta. „Twórca w dobie Internetu. Na przykładach polskiej e-literatury”. Porównania, 2 (23), 2018, s. 13-33.

Wojtczak, Dariusz. Siódmy krag piekta. Antyutopia w literaturze i filmie. Poznań, Rebis, 1994.

Zawojski, Piotr. „Monitory między nami. O byciu razem i osobno w cyberprzestrzeni”. Wiek ekranów. Przestrzenie kultury widzenia. Red. Andrzej Gwóźdź, Piotr Zawojski. Kraków, Rabid, 2002, s. 423-431. 
